\title{
MOBILE OPERATOR ADVERTISING: CRITICAL DISCOURSE ANALYSIS
}

\author{
Kharis Marpurdianto \\ Universitas Airlanggga \\ kharis.marpurdianto@gmail.com \\ Submit, 04-07-2020 Accepted, 30-12-2020 Publish, 30-12-2020
}

\begin{abstract}
This research examines contextual meaning contained in the mobile operator's advertisement in Indonesia. It focuses on how the form of cohesion and coherence, the form of word choice, and the grammatical element found in mobile operator's advertising discourse in Indonesia. A descriptive qualitative method with the content analysis technique is used as the methodology in this study. Using these methods, the researcher can give a wider understanding of the linguistic lessons through the theory of critical discourse analysis. The data is taken from mobile operator's advertisement and some books and journals. As a result of this study, the researcher found a form of word choice, cohesion and coherence as well as grammatical elements that emerged in mobile operator's advertisement discourse including non-standard variety. The advertisement language replicates from competitors that feature cheap phone rates. Moreover, there is a contextual meaning in word choice of Indonesian discourse in mobile carrier advertisement.
\end{abstract}

Keywords: Advertisement, Mobile Operator, Critical Discourse Review.

\section{INTRODUCTION}

Advertising is a news notice to the public about goods or services sold, whether posted in mass media such as newspapers and magazines. According to Darmawan (2005), an advertisement will always live and be at anytime and anywhere in our lives. The key to the success of an advertisement lies in the creativity of the people involved in the manufacturing process. Siminto (2009) stated that an advertisement is created carefully by taking the aspect that can be accepted by the general public.

In Indonesia, one of the most popular ads is the mobile carrier AD. Various types of service providers are present in Indonesia. They compete to promote their trades either through the media such as television, radio, and even the big billboards that exist in each intersection of the red light. The various advantages promoted by mobile operators are delivered through a language and of course they create a language that attracts customers with a choice of creative words. 
According to Mulyana (2005), a form of discourse is required to have a whole structure and components that have been established in an organization of citizenship are things that build wholeness in a discourse. In addition, there are three very important things in a writing, the first being the cohesion, the two coherency, and the third is the grammatical elements. Cohesion and coherence are the absolute and must be in a writing and that will reflect the content of the writings that will be read by other people who read it. In addition, in a writing, we are also obliged to pay attention to the elements of the grammatically. That is, if we create an advertisement by giving the right word choice can be expected a fish can give a positive learning or education in various circles and communities in Indonesia so that they are ashamed to do a deed and behavior that is not good or negative. One of them is through satire which is sarcasm capable to reveal the condition of social, political, cultural, and others.

Based on the research of discourse analysis and linguistic learning on Angela Chamber study of Language learning as discourse analysis: Implications for the LSP learning environment, it can be concluded that from the mid-twentieth century onwards, discourse-based approach is important for the development of linguistic and language learning (Chambers, 2007).

Discourse Analysis of Politicians' Social Media Post which analyzed on the use of social media for political figures. The study found that three political figures with most followers in three most popular social media platforms represent their nationalism and Islamic identity in their social media posts. They also convey their opinions about the general political issues in spite of divisive political condition among public that is also visible among politicians (Azmi, et.al, 2018). Another discourse analysis of critical discourse conclude that it is not only textual aspect that is important, but also contextual aspect should obtain more understanding (Bulan \& Kasman, 2018). Discourse analysis can be used on Critical moment language such as political issues, indicated that discourse analysis can describe the micro, mezzo, and macro as well as the social, political and cultural situation from the linguistic aspects (Putra \& Triyono, 2018). Discourse can also be used as an effort to change social reality (Karlberg, 2005).

Furthermore, on discourse analysis on advertisement, the truths of the conveyed messages by the advertisement are clarified, ambiguities will still remain that will affect the understanding and response of the readers or potential buyers (Sukrisno, 2010). Based on the analysis of discourse in Japanese beauty product, certain discourse used as strategies by advertisers to manipulate consumers for purchasing their product. Those strategies can be exaggerating their quality or playing with the emotion of consumers (Lestari, 2020). While the analysis about the Advertising Discourse, it was obtained that the discourse in advertisement affect costumer beliefs through discourse and the effectiveness of 
Critical Discourse Analysis in its application on advertising phenomena (Baig, 2013).

Language is a medium for people to communicate. Through language, people can express their ideas, thoughts, and feelings. However, nowadays the language definition has evolved to function not only as a means of communicating. Nowadays, language has become an intermediary medium in the implementation of power through ideology. Even language also contributes to the process of domination against others by others (Fairlclough, 1989).

Based on succinctly and several previous study that has been analyzed the importance of discourse and it is relation to influence consumer of a product on advertisement, this study aims to explain and describe the choice of words used in Advertisement language. It is hoped that a further study can be determined a pattern of choice in a word in the Indonesian-language advertising discourse and what can attract the expressed attention of consumers in the form of a very short impression. In addition, we can know the meaning of what reference is contained in the discourse of Indonesian advertising especially mobile carrier ads.

\section{LITERATURE REVIEW}

Kridalaksana in Darma (2009) provided an explanation of discourse is the most complete language unit in the highest grammatical hierarchy and is the largest or highest grammatical unit. A discourse can affect and be influenced by social context. Fairlclough described discourse as a form of "social practice" which implicates the existence of dialectics between language and social conditions (cited in Lestari, 2020). In the eye glasses critical discourse analysis, according to Fairlclough and Wodak (cited in Van Dijk, 1977) the practice of discourse could be display ideology: it can produce unbalanced power relationships between social classes, men and women, majority groups and minorities. The difference in that social position is shown through discourse, for example, in a discourse of a racist state, sexist, or the inequality of social life, is depicted reasonably/naturally, and accordingly as in reality.

The purpose of the critical discourse analysis is to explain a dimension in the linguistic lessons of cultural and social phenomena, as well as the process of change occurring in the latest modernity. In a text analysis, Sudaryat (2008) defines that the cohesion is a solid, cohesive sentence that produces a speech. In other words, the meaning between the elements in the text is very important to interpret a text, the harmony of the relationship between one element and the other in a discourse.

There were three literature studies which examined the critical discourse analysis (AWK). The first was Abdul Muizzu, a student UIN Sunan Kalijaga Yogyakarta, with his thesis entitled "Sikap Media Massa Terhadap Kasus 
Pimpinan KPK Bibit Samad Rianto dan Chandra M. Hamzah (Analisis Wacana Kritis Tajuk Rencana Kompas Edisi November 2009)" found that the attitude of Harian Kompas is tend to support Bibit and Chandra rather than Police and Prosecutors. The support cannot be separated from its character as mass media that keep on trying to muted the conflict due to national stability (Muizzu, 2011). Another study came from Laelatul Pathia in her study entitled "Analisis Wacana Kritis dalam Bahasa Media Jejaring Sosial Twitter" showed that public can define the image of somebody else through language they used. Even though the language that is delivered is simple but it is able to give greater impact in life (Pathia, 2014), and the third was coming from STKIP PGRI Bandar Lampung student, Andri Wicaksono, who indicated that language used in the slogan has meaning to convey (Wicaksono, 2016).

Thus, from the previous studies above, it can be seen that the focus used in this study has similarity with those previous studies that is the analysis of critical discourse. However, the researcher here used different object and media as well as Fairlclough (1989) method to analyze mobile operator's advertisement discourse.

\section{RESEARCH METHOD}

This research is a study using qualitative descriptive methods with the technique of content analysis. The Critical Discourse Analysis (CDA) of the Fairclough model is the analysis used in this study. Firstly, each text simultaneously has three functions that must be met, among other things, representation, relationships, and identity. Secondly, practice in discourse covers the ways in which media workers produce a text. It is also related to other media workers, media work as an institution, such as how to cover a news story, write news, until it becomes news in a media. Thirdly, the practice in socio-cultural analyzing three things i.e. economics, politics (especially related to power and ideology issues) and culture (which is especially related to the value and identity) that also affects media institutions and its discourse. In its application, the analysis of the discourse is an analysis of the three dimensions of critical discourse, which is the dimensions of text, dimensions of discourse, and sociocultural dimension.

The analysis material is the text in an advertising discourse of the mobile operator in attracting the attention of the mobile phone card user. In digging and collecting data, researchers use several data collection techniques, namely document studies by utilizing a variety of document materials in written documents, drawings, works, and electronics. Afterwards, the documents that have been analyzed, it will be compared, and combined to form a systematic, solid, and intact study. 


\section{FINDINGS}

Simpati Mobile Operators Create one of the advertising promotions that appeal to users by creating episodes of a family story in "Weekly package Make full" in the data 1 Simpati card version of the brain is an advertisement that advertises "Satian package" from Simpati cards. In an export, full Internetan package includes an imaging metaphor because the operator uses figurative language (a language that uses metaphorical meanings rather than literally or literally meaning) to convey an information. The purpose of the phrase "full Internet package" is a cheap Internet package and satisfying users of Simpati cards in Indonesia. In addition, the price is cheaper and able to reach by anyone and give satisfaction to each user. Starting from teenagers, until the parents, even from any layer of society (whether or not able to do) can use the "full Internetan package". This is evident from the diversity of characteristics that family members have on Simpati card advertisements.

Based on the explanation above, the sentence "Full Internet Package" is used by the operator to offer a satisfaction and freedom for all users of Simpati card in choosing the desired package with a price starting from 5000 rupiah. It is in line with the opinion of Larson (1998:271) which defines that, metaphor is a figurative expression based on comparison.

The operator of Simpati, insinuated operators XL, it has been seen from the words in an advertisement star of Simpati operators.

"Quiet, quiet, anyway I've been tobat, only the cheapest Simpati cards direct from the first minute Gak Ribet, there is not its boundaries, Morning, noon, night. I am a little boy kapok.

The intention of the least inexpensive phrase is that Simpati cards have an advantage that other cards don't have, we do not have to wait until 2 minutes to get a cheap package as it happens on the other cards, do not need to be long at the time we check the quota, and there is no time limit for usage from morning to night, unlike other operators who must check quota first, and have time limit of usage. Operators want to attract users ' attention by using the least inexpensive, uncomplicated, and most important phrases, no usage time limits.

Advertisement XL "blessing to share". "Buy a new smartphone with a starter card, can be YouTube without 1 year quota". In the advertisement is very clear if the XL Operator insinuated the Simpati Operator. In an advertisement, there appears a mobile store (the nuance of blue shops including clothing employees, similar to the color of Operator XL card) is closed because all customers switch to the XL Operator store that offers cheaper package.

"A blessing to share." Buy a new smartphone with a starter card, can be YouTube without one-year quota. A blessing to share the use of XL Operator to draw the attention of XL's first card users, each user is entitled to a variety of 
benefits in the form of 1 year Youtube without quota, unlimited calls with the application Whatsapp and Line (including voice call and Video Call), and watch movies Indonesia through the latest FREE subscription application XL Super watch. The users are guaranteed not to lose to buy the starter card on XL. The sentence "blessing to share" in an express, including a metaphor, because in the sentence of blessings to share, the OPERATOR of XL intends to provide a picture of information using figurative language on each user, THAT the XL card can provide various advantages for every user of the starter card. Using an XL card the user will get a lot of profit. It is thought of by the opinion of Larson (1998:271) explaining that metaphors are figurative phrases that have been based on comparisons.

Another version of XL advertisement "The CHEAP is RP 25 from the first minute". In the ad, Baim Wong was told by Princess Titular to comment, "Om sule handsome", but with innocence and honesty (which of course has been engineered by the director) Baim said, "Om Sule is Ugly". Sule then persuades Baim and gives Baim two pieces of food, hoping that Baim will say "Om Sule handsome". But Baim still answered what there was like the previous answer. "From the first, Om Sule was ugly". "From The first If the Rp. 25,-the card XL, the cheap Beneran" replied Baim again. "From the first if it is Rp. 25,the $\mathrm{O} 2$ card, the cheap Beneran, through the sentence, the operator wants toinformation on the user, that the card XL really cheap start minutes first. The advertisements delivered are true to reality, not just to attract the attention of XL card users.

The Word beneran is an unraw form of the word true. The right word- has the meaning that corresponds to- How it is, right, not wrong. In the Indonesian language is adjectives. His cheap is an adjectives word that gets his klitik. Klitik variant of the pronominal persona he or he and pronominal objects stating belongs, perpetrators or receivers (Alwi, 2003). Traditionally, adjectives known as a kaa that gives a more specific description of something expressed in a sentence.

The advertisement of other Simpati operators, "the real super hero, regardless of charisma, here are 2 Super Cak Noris characters wearing the super. Save just 5000 rupiah, can make Nelfon, SMS, Internet all day Unlimited, Super good right.

Based on the above data, through the word Super, the Operator Simpati wants to convey an information and that attracted attention to every user, that the Simpati cards have an advantage and Istimewaan compared to the other cards. All these advantages are only owned by Simpati cards. The Operator uses the word Super as a power to attract users ' attention.

Gramatics, the word Super includes an adjective. Super means more than any other, extraordinary, special (KBBI). Adjectives are known as words that 
reveal the quality or circumstances of an object. A word that-provides more specific information about something expressed in a sentence (Alwi, 2003).

Choose the maximum, best quality, no risk plan. Unlimited calls and SMS. Connect millions of people, bringing together millions of hearts. Through the sentence, the advertising Operator wants to attract users and convey an information that Simpati cards have the best of the same in comparison with other operators, without any risk, can call and SMS without fear of running out of pulse. So it is able to connect millions of people including family, friends, girlfriends, and others.

This sentence: linking millions of people, bringing together millions of Hearts including imaging metaphors, because operators use figurative language, phrases to attract users ' attention to use Simpati cards. It is in line with the opinion (Classe, 2000) about the metaphor of the use of imagery, meaning, or quality of a phrase to another expression. The transfer is done by referring a concept to another concept to imply the similarity, analogy or relationship of both concepts.

"Change has come, for a better digital world, enjoy everything you like, faster and stay faster anywhere" "with a powerful data network in Indonesia, it can connect with millions of friends anywhere, and at no extra cost, 4GP for all."

In the sentence above, the operator wants to convey that the XL card has a new breakthrough, with a stronger and faster data network, we can connect with many people anytime and anywhere at no extra cost. The meaning of the sentence faster in the text is faster to connect in a short time can connect with anyone and anytime at a cheap cost. The Operator uses the word faster to get a response from the card user, so it is interested to use an XL card. It is quicker to include the phrase adjective, because it is faster composed of two words and does not exceed the function limit. This is in line with Ramlan's opinion of the phrase, which is a grammatically consisting of two or more words that do not exceed a boundary of function contained in the clause (Ramlan, 2001).

Furthermore, XL does not seem to be hooked. XL is offering a new concept in its promotional strategy as written below;

Lokasi di swalayan (Location at supermarket)

Perempuan: Beli Tisu dong (Woman: I want to buy Tissue)

(Seisi swalayan keluar dari took) (Everyone is out from the supermarket)

HaaaAaaAAh

Lokasi di halte bus (Location at bus stop)

Perempuan: Geser dikit dong (Woman: Please move a bit)

(Semua orang yang berada di halte lari tunggang langgang)

(Everyone at the bus stop run in chaos) 
Perempuan masuk ke dalam bus (Woman gets into the bus)

(Seisi bus keluar sambil menjerit histeris)

(The bus passengers out and screaming hysterically)

Tulisan disamping (Posts on the slide)

"KORBAN KETAGIHAN SMS"

"SMS ADDICTION VICTIMS"

"SMS-AN 100\% GRATIS GAK ADA BATAS KE SEMUA OPERATOR"

"Sending message is $100 \%$ FREE with NO LIMITS TO ALL OPERATORS"

Narator: ini dia korban ketagihan sms XL

Narrator: Here is the victim of SMS XL addict.

The language of the ads used is a colloquial language in conversation with non-standard speech act or a variety of slang in conversations between speakers of comparable age. The sentence is incomplete and the following word is a variety of unfledged blend, mixing code with regional or local language in the textual dialogue ad.

"The"

"The Little Move"

"SMS-an..."

In an advertisement discourse, the coherence aspect is indispensable to its existence to maintain an inner connection between the other's propositions to gain integrity. The coherent integrity is described by the existence of the relationship between-the elements (part) semantically. Advertising is a way of communicating with the community so that it is tailored to the products and target market. Each ad contains a message that wants to be delivered to the public.

Not much different from the ads offered by the company's Operator XL, the operator of sympathy also wanted to show the imagery that they offer the lowest fares.

13 minutes to chat, do not be dashed, and continue. Simpati tariff until the 13 th minute, remained 0.5/second. Simpati one for 1001 of desire! Telkomsel reaches to remote Indonesia.

To all operators and landlines, 24 hours nonstop. SMS only Rp 88, call only Rp 13 per second. Love... Simpati cards, make your life more colorful.

From the two ads above, the first mentioned that up to the 13th minute, the cost of consumers spent only enough for 0.5 rupiah per second. This offer is done by Telkomsel Company with Simpati card products, which offer unlimited call to all operators and 24-hour landline. 


\section{DISCUSSION}

According to Fairclough, discourse is focused on language since it usage used to reflect something. Discourse is a form of an act and used as representation in seeing reality. It also indicated the relationship between discourse and social structure. The language within an advertisement should be delivered in clear and strong language (Saraswati \& Sartini, 2017). In XL and Simpati advertisement, the coherence between sentences can be seen through sentences that served in structure. Coherence is a part of a discourse as semantic organization and term that arranged in logical sequence to get the meaning. Every mobile operator is compete to lower the price, give free message and phone call, cheap internet data and others.

In this case, XL Operator use different strategy. The Ghost ad-information message is addicted to send SMS. The advertisement of a woman whose fun of sending SMS to forget yourself. XL uses the female ghost icon in his ad impressions. Though there are still many other friendlier icons that can be-used for ad impressions. These ghost impressions can be detrimental to psychological and psychiatric. This also applies to ads and other movie impressions that use ghost icons. The advertisement is portrayed as a white woman with a face covered with long hair like a ghost, XL advertising products complained of many parties.

These ads do not educate and judged to be mentally damaging to children. Moreover, the advertisement aired almost hourly. The impression of a female ghost in XL advertisement frightens children. Moreover, the ad impressions of the Indonesian version of Kuntilanak (Indonesian ghost) are routinely and repeatedly, especially in national television.

On the other uses, as the response of ad impression, an advertiser's advertising agency or an advertiser's company should respect the views and input of the community to stop the ghost ads from XL. If not stopped, other products will follow up creating ads-. To decide on the sustainability of the ad requires a technical procedure including a "placement" contract with the television station that advertisements the ad. That takes time to process them. But, in spite of all that, The Advertiser has absolutely no intention of damaging the young generation of mentally incoming children through the delivery of such ghost advertisements.

\section{CONCLUSION}

Based on the analysis, it can be concluded that the preferred form of word, cohesion and coherence as well as grammatical elements are appearing in the mobile operator's advertising discourse including the non-standard variety. The advertising language replicates from competitors that feature cheap phone rates. There is a contextual meaning contained in the choice of words of the Indonesian advertising discourse in mobile carrier ads. The language-spoken in 
the mobile operator's slogan or the words choice used by the provider has meaning to convey, by reflecting the character of each service company providers. Thus, with the growing variety of mobile operators in Indonesia, the competition to get attention or interest from customers is raised. Furthermore, advertising is already become a part of life and it is undeniable. Advertisements have provided livelihoods for various sectors, either directly or indirectly. Starting from advertising services, printing, media, actor/actress as advertising stars and others that dredge profits. Advertisements are created and served in a creative process and not intended to harm others. It is a creative process in communicating with the public or society. However, a frequent way of communicating is may be accepted or perceived differently by people.

\section{REFERENCES}

Alwi, H. (2003). Tata Bahasa Baku Bahasa Indonesia. Jakarta: Balai Pustaka.

Azmi, A., Sylvia, I., \& Mardhiah, D. (2018). Discourse Analysis of Politicians' Social Media Posts. Jurnal The Messenger, 10(2), 174. https://doi.org/10.26623/themessenger.v10i2.792

Baig, M. (2013). Analyzing the Advertising Discourse- A Journey from Sight to Mind. International Journal of Applied Linguistics \& English Literature, 2(1), 126-135. https://doi.org/10.7575/ijalel.v.2n.1p.126

Bulan, A., \& Kasman, K. (2018). Critical Discourse Analysis of Ahok's Speech in Kepulauan Seribu. Transformatika: Jurnal Bahasa, Sastra, dan Pengajarannya, 2(1), 50. https://doi.org/10.31002/transformatika.v2i1.555

Chambers, A. (2007). Language Learning as Discourse Analysis: Implications for the LSP Learning Environment. ASp, (51-52), 35-51. https://doi.org/10.4000/asp.483

Classe, O. (2000). Encyclopedia of Literary Translation into English. London: Fitzroy Dearborn Publishers.

Darma, Y. A. (2009). Analisis Wacana Kritis. Bandung: CV Yrama Widya.

Darmawan, F. (2005). Posmodernisme Kode Visual dalam Iklan Komersial. Jakarta: Jurnal Komunikasi Mediator.

Fairlclough, N. (1989). Language and Power. New York: Addison Wesley Longman.

Karlberg, M. (2005). The Power of Discourse and the Discourse of Power: Pursuing Peace through Discourse Intervention. International Journal of Peace Studies.

Lestari, E. M. I. (2020). A Critical Discourse Analysis of The Advertisement of Japanese Beauty Products. IZUMI, 9(1), 58-74. https://doi.org/10.14710/izumi.9.1.58-74

Muizzu, A. (2011). Sikap Media Massa Terhadap Kasus Pimpinan KPK Bibit Samad Rianto dan Chandra M. Hamzah (Analisis Wacana Kritis Tajuk Rencana Kompas Edisi November 2009). UIN Sunan Kalijaga Yogyakarta. 
Mulyana. (2005). Kajian Wacana Teori Metode, dan Aplikasi Prinsip-Prinsip Analisis Wacana. Yogyakarta: Tiara Wacana.

Pathia, L. (2014). Analisis Wacana Kritis dalam Bahasa Media Jejaring Sosial Twitter. UIN Sunan Kalijaga Yogyakarta.

Putra, H. P., \& Triyono, S. (2018). Critical Discourse Analysis on Kompas.com News: "GERAKAN \#2019GANTIPRESIDEN." LEKSEMA: Jurnal Bahasa dan Sastra. https://doi.org/10.22515/ljbs.v3i2.1412

Ramlan, M. (2001). Morfologi Suatu Tinjauan Deskripsi. Yogyakarta: CV. Karyono.

Saraswati, A., \& Sartini, N. W. (2017). Wacana Perlawanan Persebaya 1927 terhadap PSSI: Analisis Wacana Kritis Norman Fairclough. Mozaik Humaniora, 17(2), 181-191.

Siminto. (2009). Analisis Wacana Iklan Televisi Rokyo Rasa Terasi dalam Sumarlan, Agnes Adhani dan Indratmo. Bandung: Pakar Raya.

Sudaryat, Y. (2008). Makna Dalam Wacana. Bandung: Yrama Widya.

Sukrisno, A. (2010). Discourse Analysis on Advertisement. Language Circle Journal of Language and Literature, 4(2).

Van Dijk, T. A. (1977). Text and Context: Exploration in the Semantics and Pragmatics of Discourse. London: Longman.

Wicaksono, A. (2016). Analisis Wacana Kritis Iklan Operator Seluler. STKIP PGRI Bandar Lampung. 